\title{
Modern methods of surgical treatment of anal canal and rectum combined pathology
}

V. V. Balytskyy ${ }^{1,2}$, M. P. Zakharash ${ }^{3}$, O. G. Kuryk ${ }^{3}$

${ }^{1}$ National Pirogov Memorial Medical University, Vinnytsya,

${ }^{2}$ Khmelnytskyi regional hospital,

${ }^{3}$ Bogomolets National Medical University, Kyiv

\section{Сучасні методи хірургічного лікування поєднаної патології анального каналу і прямої кишки}

\author{
В. В. Балицыкий ${ }^{1,2}$, М. П. Захараш ${ }^{3}$, О. Г. Курик ${ }^{3}$ \\ ${ }^{1}$ Вінницький національний медичний університет імені М. І. Пирогова, \\ ${ }^{2}$ Хмельницька обласна лікарня, \\ ${ }^{3}$ Національний медичний університет імені О. О. Богомольця, м. Київ
}

\begin{abstract}
Objective. To evaluate the effectiveness of surgical treatment of anal canal and rectum combined pathology, through combined surgical interventions using modern electro- and radiosurgical technologies.

Materials and methods. A comparative evaluation of the results of surgical treatment of 681 patients with combined pathology of the anal canal and rectum, who underwent combined single-stage operations using high-frequency electrosurgery and radio-wave surgery.

Results. In case of application the device for radio-wave surgery "Surgitron", and also devices of high-frequency electrosurgery "ERBE ICC 200", "EFA", "KLS Martin" duration of operation is reduced to (15 - $25 \pm 3)$ minutes, volume of blood loss decreases to $(15 \pm 6) \mathrm{ml}$, the need for narcotic analgesics decreases up to $(2 \pm 1) \mathrm{ml}$, the duration of inpatient treatment was reduced up to $(4 \pm 1)$ days.

Conclusions. The use of modern radio- and electrosurgical technologies for the treatment of combined anorectal pathology prevents the occurrence of anal canal strictures and scarring of the perianal areas, causing the cosmeticity of combined operations.

Keywords: combined pathology of the anal canal and rectum; combined operations; apparatus of radio wave surgery "Surgitron"; high-frequency electrosurgery devices "ERBE ICC 200", "EFA", "KLS Martin".

Реферат

Мета. Оцінка ефективності хірургічного лікування поєднаної патології анального каналу і прямої кишки, яке полягало у виконанні комбінованих оперативних втручань з використанням сучасних електро- та радіохірургічних технологій. Матеріали і методи. Проведена порівняльна оцінка результатів хірургічного лікування 681 пацієнта 3 поєднаною патологією анального каналу і прямої кишки, якому були виконані комбіновані одноетапні операції з використанням апаратів високочастотної електрохірургії та апарата радіохвильової хірургії.

Результати. У разі застосування апарата радіохвильової хірургії «Surgitron», а також апаратів високочастотної електрохірургії «ERBE ICC 200», «ЭФА», «KLS Martin» скорочується тривалість операції до (15 \pm 3$)$ хв, зменшуються об’єм крововтрати

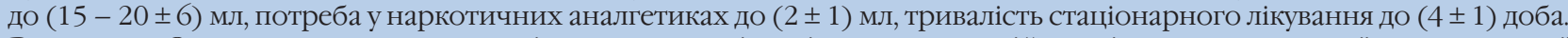
Висновки. Застосування сучасних радіо- та електрохірургічних технологій для лікування поєднаної аноректальної патології запобігає виникненню стриктур анального каналу та рубцевих деформацій періанальних ділянок, обумовлюючи косметичність комбінованих операцій.
\end{abstract}

Ключові слова: поєднана патологія анального каналу і прямої кишки; комбіновані операції; апарат радіохвильової хірургії «Surgitron»; апарати високочастотної електрохірургії «ERBE ICC 200», «ЭФА», «KLS Martin».

To date, there is no single approach to surgical treatment of combined pathology of the anal canal and rectum. In addition, a rather small number of scientific studies are dedicated to this problem [1]. Thus, some authors consider combined procedures for combined anorectal pathology acceptable, as they reduce the length of hospital stay and prevent re-operation [2], while others believe that this approach significantly increases the number of complications and should be performed only in selected cases. However, most authors are convinced that combined procedures have undeniable advantages: radical surgical treatment of $2-3$ ano- rectal pathologies, no need for re-anesthesia, prevention of complications, reduction of hospital stay and decrease the cost of treatment [3].

The choice of strategy and method of surgical treatment of combined pathology of the anal canal and rectum, which provide minimal impact on the tissues to prevent postoperative complications, requires a special approach [4].

Over the last decade, laser technologies have been widely used in the treatment of various anorectal pathology due to their advantages: low trauma, laser destruction within the submucosal layer, no intraoperative bleeding, short oper- 
ations, no inflammatory complications and postoperative scars in the affected area, shortening of terms of treatment [5]. But laser technology, unfortunately, has a number of disadvantages: postoperative bleeding (1.97-2.2\%), emerging of hemorrhoids (2.2 - 18.9\%), postoperative edema in the coagulation zone $(6.2-33.1 \%)$, recurrence of diseases $(5.42-41.7 \%)$, the formation of residual hemorrhoidal skin marks (14.5\%), long-term healing of anal canal wounds $(5.6 \%)[6-11]$.

Thus, the high relevance of the problem of combined pathology of the anal canal and rectum dictates the need to develop new highly effective methods of surgical treatment using modern technologies that would provide less postoperative complications, prevent recurrences in the postoperative period and thus contribute to rapid social and rehabilitation of patients.

The aim of the study: to evaluate the effectiveness of surgical treatment of combined pathology of the anal canal and rectum, which consisted of performing combined surgical interventions using modern electrosurgical and radiosurgical technologies.

\section{Materials and methods}

In the period from January 2007 to April 2021 in the proctology department of Khmelnytsky Regional Hospital 681 patients underwent surgical treatment of combined pathology of the anal canal and rectum using the device of radiowave surgery "Surgitron", as well as devices of high-frequency electrosurgery "ERBE ICA 200", «KLS Martin».

There were 378 men (55.5\%) and 303 women (44.5\%). The age of patients ranged from 18 to 76 years.

The first group included 245 (35.9\%) patients who were treated using a radio-wave surgery device "Surgitron", the second group - 169 (24.8\%) patients who underwent surgery with a high-frequency electrosurgery device "ERBE ICC 200", in the 3rd group - 114 (16.7\%) patients - with the device of high-frequency electrosurgery "EFA", in the 4th group - 153 (22.5\%) patients - using a high-frequency electrosurgery device "KLS Martin".

The control group consisted of 112 patients with combined pathology of the anal canal and rectum, who underwent standard procedure using a metal scalpel. All surgeries were performed under spinal anesthesia.
After surgical interventions using the device of radiowave surgery "Surgitron", as well as devices of high-frequency electrosurgery "ERBE ICC 200", "EFA", "KLS Martin", morphological examination of tissues was performed to study the depth of their necrosis. The thickness of the coagulation necrosis layer was measured using an eyepiece-micrometer scale.

The operating material was fixed in 10\% neutral formalin solution. Next, the material was processed in a carouseltype STP-120 histoprocessor, the EC-350 station was used to fill paraffin blocks, a rotary microtome of the HM-340E series was used to cut paraffin blocks, and a Robot-Stainer HMS-740 machine was used for staining histological specimens (all machines manufactured by Karl Zeiss MICROM International $\mathrm{GmbH}$, Germany). The drugs were stained with hematoxylin and eosin. An Axioskop 40 microscope with an Axio Cam MRc5 camera (Karl Zeiss) was used.

SPSS software was used for statistical analysis of the obtained data. The distribution for normality was checked using the Kolmogorov-Smirnov criteria with the Lilliefors and Shapiro-Wilk corrections. The equality of variances was checked using the Livin test. The critical level of statistical significance was 0.05 .

In groups with homogeneous variances, where the values of the indicators were distributed normally, one-way analysis of variance was used for comparison, and for pairwise comparison - Bonferoni test. In groups with homogeneous variances, where the values of the indicators were not normally distributed, the Kraskel-Wallis test was used for comparison, and the Mann-Whitney test was used for pairwise comparison.

For pairwise comparison of groups, the adjusted critical significance level was defined as 0.0050-05/10, because 5 groups were compared and 10 pairwise comparisons were performed.

\section{Results}

The distribution of patients in groups by the number of combined diseases is presented in Table 1.

The most common variants of combined pathology of the anal canal and rectum, which occurred in all study groups and the type of the performed surgical interventions are presented in Table 2.

Table 1. Distribution of patients in the study groups by number

\begin{tabular}{|c|c|c|c|c|c|c|c|c|}
\hline \multirow{3}{*}{ Study groups } & \multicolumn{8}{|c|}{ Number of combined diseases } \\
\hline & \multicolumn{2}{|c|}{ two } & \multicolumn{2}{|c|}{ three } & \multicolumn{2}{|c|}{ four } & \multicolumn{2}{|c|}{ five } \\
\hline & $\mathrm{n}$ & $\%$ & $\mathrm{n}$ & $\%$ & $\mathrm{n}$ & $\%$ & $\mathrm{n}$. & $\%$ \\
\hline $\begin{array}{c}1 \mathrm{st} \\
(\mathrm{n}=245)\end{array}$ & 188 & 76,7 & 51 & 20,8 & 6 & 2,4 & - & - \\
\hline $\begin{array}{c}2 \mathrm{nd} \\
(\mathrm{n}=169)\end{array}$ & 132 & 78,1 & 35 & 20,7 & 2 & 1,2 & - & - \\
\hline $\begin{array}{c}3 \mathrm{rd} \\
(\mathrm{n}=114)\end{array}$ & 85 & 74,6 & 26 & 22,8 & 3 & 2,6 & - & - \\
\hline $\begin{array}{c}4 \text { th } \\
(n=153)\end{array}$ & 97 & 63,4 & 48 & 31,4 & 6 & 3,9 & 2 & 1,3 \\
\hline
\end{tabular}


Table 2. The most common variants of combined pathology in the studied groups and the nature of the performed surgical interventions in them

\begin{tabular}{|c|c|c|c|}
\hline \multirow{2}{*}{ Option of combined pathology } & \multirow{2}{*}{ The nature of the performed surgical interventions } & \multicolumn{2}{|c|}{ Number of patients } \\
\hline & & $\mathrm{n}$ & $\%$ \\
\hline Chronic anal fissure and anal polyp & Excision of the anal fissure and polypectomy & 115 & 16,9 \\
\hline Chronic anal fissure and combined hemorrhoids & $\begin{array}{l}\text { Hemorrhoidectomy and excision of the anal } \\
\text { fissure }\end{array}$ & 84 & 12,3 \\
\hline $\begin{array}{l}\text { Combined hemorrhoids and chronic } \\
\text { paraproctitis }\end{array}$ & $\begin{array}{l}\text { Hemorrhoidectomy and excision of the anal } \\
\text { fistula }\end{array}$ & 62 & 9,1 \\
\hline Combined hemorrhoids and anal polyp & Hemorrhoidectomy and polypectomy & 61 & 9,0 \\
\hline $\begin{array}{l}\text { Chronic anal fissure, anal polyp } \\
\text { and hypertrophied perianal skin marks }\end{array}$ & $\begin{array}{l}\text { Excision of the anal fissure, polypectomy } \\
\text { and electroexcision of hypertrophied perianal } \\
\text { skin marks }\end{array}$ & 40 & 5,9 \\
\hline $\begin{array}{c}\text { Combined hemorrhoids, chronic anal fissure } \\
\text { and anal polyp }\end{array}$ & $\begin{array}{l}\text { Hemorrhoidectomy, anal fissure excision } \\
\text { and polypectomy }\end{array}$ & 29 & 4,3 \\
\hline Chronic paraproctitis and anal polyp & Excision of the anal fistula and polypectomy & 23 & 3,4 \\
\hline External hemorrhoids and anal polyp & Hemorrhoidectomy and polypectomy & 21 & 3,1 \\
\hline External hemorrhoids and chronic paraproctitis & $\begin{array}{l}\text { Hemorrhoidectomy and excision of the anal } \\
\text { fistula }\end{array}$ & 21 & 3,1 \\
\hline External hemorrhoids and chronic anal fissure & $\begin{array}{l}\text { Hemorrhoidectomy and excision of the anal } \\
\text { fissure }\end{array}$ & 20 & 2,9 \\
\hline $\begin{array}{l}\text { Chronic anterior anal fissure, chronic posterior } \\
\text { anal fissure and anal polyp }\end{array}$ & Excision of anal fissures and polypectomy & 18 & 2,6 \\
\hline $\begin{array}{c}\text { Anal polyp and hypertrophied perianal skin } \\
\text { marks }\end{array}$ & $\begin{array}{l}\text { Polypectomy and electroexcision of } \\
\text { hypertrophied perianal skin marks }\end{array}$ & 16 & 2,3 \\
\hline $\begin{array}{l}\text { External hemorrhoids, chronic anal fissure } \\
\text { and anal polyp }\end{array}$ & $\begin{array}{l}\text { Hemorrhoidectomy, anal fissure excision } \\
\text { and polypectomy }\end{array}$ & 12 & 1,8 \\
\hline $\begin{array}{l}\text { Chronic anal fissure, anal polyp and chronic } \\
\text { paraproctitis }\end{array}$ & $\begin{array}{l}\text { Excision of the anal fissure, polypectomy } \\
\text { and excision of the anal fistula }\end{array}$ & 11 & 1,6 \\
\hline Combined hemorrhoids and acute paraproctiti & Hemorrhoidectomy, excision of the abscess & 11 & 1,6 \\
\hline
\end{tabular}

Comparative characteristics of high-frequency electrosurgical devices "ERBE ICC 200", "EFA", "KLS Martin", radio-wave surgery "Surgitron", as well as a metal surgical scalpel in the surgical treatment of patients with combined pathology of the anal canal and rectum are presented in Table 3.

Comparison of groups by the Kraskel-Wallis test revealed a statistically significant difference between them with a significance level of $\mathrm{p}<0.001$ for all indicators. In a pairwise comparison of groups according to the Mann-Whitney test, no statistically significant difference was found in the indicator "Duration of the operation" between the 3rd and 4th groups; according to the indicator "Volume of blood loss" between the 1st and 3rd, 1st and 4th, 2nd and 3rd, 2nd and 4 th, 3 rd and 4th groups; according to the indicator "Severity of pain" between the $3 \mathrm{rd}$ and 4th groups; according to the indicator "Duration hospital stay" between the 3rd and 4th groups; according to the indicator "Depth of the coagulation necrosis layer" between the 2nd and 3rd, 2nd and 4 th, 3 rd and 4 th groups. Among other pairs of groups, statistically significant differences were found at the level of significance $p<0.001$. Comparison of all groups with the control group showed statistically significant differences between them in all indicators.

In the postoperative period, there were no patients with scar stricture of the anal canal, while in the control group in
$2(1.8 \%)$ patients scar stricture of the anal canal developed, which required conservative (1 patient) and surgical (1 patient) treatment to eliminate them.

\section{Discussion}

The use of Surgitron radiosurgery device for the treatment of patients with combined pathology of the anal canal and rectum was associated with the formation of the thinnest layer of coagulation necrosis in the tissues, the depth of which ranged from 0.085 to $0.211 \mathrm{~mm}$, thus patients in the 1st study group had less pain, postoperative wounds healed faster and the duration of hospital stay was reduced by $3-4$ days. In addition, the duration of procedure, as well as the amount of blood loss, were half that of the control group, who underwent surgery with a metal scalpel.

The use of KLS Martin high-frequency electrosurgery device was also associated with the formation of a thin layer of coagulation tissue necrosis with a depth of 0.116 to 0.286 $\mathrm{mm}$, so that in patients of the 4th study group the intensity of postoperative pain was also insignificant and twice less than in the control group. The terms of wound healing and hospital stay were the same as in patients of the 1st study group. The duration of the procedure, as well as the volume of blood loss in patients of group 4 were also the same as in patients of group 1, and twice less than in patients of the control group. 
Table 3. Comparative characteristics of modern and standard surgical technologies used in the treatment of combined pathology of the anal canal and rectum

\begin{tabular}{|c|c|c|c|c|c|}
\hline \multirow[b]{2}{*}{ Comparison criteria } & \multicolumn{5}{|c|}{ Surgical technologies } \\
\hline & $\begin{array}{l}\text { «Surgitron» } \\
(\mathrm{n}=245)\end{array}$ & $\begin{array}{l}\text { «ERBE ICC } \\
200 »(n=169)\end{array}$ & $\begin{array}{l}\text { «EFA» } \\
(\mathrm{n}=114)\end{array}$ & $\begin{array}{l}\text { «KLS Martin» } \\
(\mathrm{n}=153)\end{array}$ & $\begin{array}{c}\text { metal surgical } \\
\text { scalpel } \\
(\mathrm{n}=112)\end{array}$ \\
\hline Duration of operation, min & $15 \pm 3$ & $20 \pm 3$ & $25 \pm 3$ & $15 \pm 3$ & $29 \pm 3$ \\
\hline Blood loss, ml & $20 \pm 6$ & $15 \pm 6$ & $20 \pm 3$ & $20 \pm 6$ & $40 \pm 6$ \\
\hline $\begin{array}{l}\text { The severity of the pain syndrome - the need } \\
\text { for narcotic analgesics, } \mathrm{ml}\end{array}$ & $2 \pm 1$ & $3 \pm 1$ & $2 \pm 1$ & $2 \pm 1$ & $4 \pm 1$ \\
\hline Duration of inpatient treatment, days & $4 \pm 1$ & $6 \pm 1$ & $5 \pm 1$ & $4 \pm 1$ & $7 \pm 1$ \\
\hline Depth of coagulation necrosis layer, $\mathrm{mm}$ & $0,148 \pm 0,063$ & $0,291 \pm 0,099$ & $0,229 \pm 0,105$ & $0,201 \pm 0,085$ & - \\
\hline $\begin{array}{l}\text { Indicators are presented as } \overline{\mathrm{x}} \pm \mathrm{SD} \text {, } \\
\text { interval of the mean. }\end{array}$ & $\mathrm{x}$ is the arith & mean, $\mathrm{S}$ is & lard deviat & $\mathrm{d} 95 \%$ of $\mathrm{tl}$ & idence \\
\hline
\end{tabular}

The effect of the high-frequency electrosurgery device "EFA" on the tissues was slightly deeper than the devices "Surgitron" and "KLS Martin", the depth of coagulation necrosis ranged from 0.124 to $0.334 \mathrm{~mm}$, accompanied by a slight increase in the intensity of postoperative pain, slightly increased the terms of wound healing and hospital stay. The duration of the operation was longer than in the 1 st and 4th study groups, and the volume of blood loss in patients of the 3 rd group was the same as in the patients of the 1st and 4th groups, and twice less than in the patients control group.

The use of high-frequency electrosurgery device "ERBE ICC 200" was associated with the least blood loss, but also the deepest impact on tissues, the layer of coagulation necrosis ranged from 0.192 to $0.39 \mathrm{~mm}$, causing the most severe pain in the postoperative period and increase in hospital stay, although still less compared to the control group.

The use of a surgical metal scalpel was associated with formation of hemorrhages in the tissues, which led to their greater trauma and, accordingly, the longest duration of operations, the greatest intraoperative blood loss, the most severe pain in control group patients, and the longest duration of hospital stay.

The minimal impact on the tissue of the radio-surgical device "Surgitron" and high-frequency electrosurgical devices "KLS Martin", "EFA" and "ERBE ICC 200" contributed to the formation of cosmetic postoperative scar, prevented scar strictures of the anal canal, thereby reducing the wound healing time with faster rehabilitation of patients in the study groups. In addition, the use of these modern radioand electrosurgical technologies was not accompanied by such a variety of complications as after the use of laser technology [9-11], which gives them significant advantages in the treatment of this category of patients.

\section{Conclusions}

1. One-stage combined surgical interventions using modern radiosurgical and high-frequency electrosurgical technologies for the treatment of combined pathology of the anal canal and rectum in comparison with standard methods contributes to a significant reduction in the duration of operations, volume of intraoperative blood loss, postoperative intensity of pain, and also the duration of hospital stay.

2. The use of modern radio- and electrosurgical technologies for the treatment of combined anorectal pathology, which is accompanied by a small depth of tissue necrosis (from 0.085 to $0.39 \mathrm{~mm}$ ), prevents strictures of the anal canal and scarring of the perianal areas, contributes to a good cosmetic result.

Finding. This research work is a fragment of the planned scientific work of the Department of Surgery No. 1 of the Bogomolets National Medical University "Development and implementation of modern technologies in surgery of the abdominal cavity, anterior abdominal wall and perineum" (state registration number 0115U000014). Source of funding: State Budget of Ukraine.

Contribution of each participant. Balytsky VV - analysis of literature data, collection and processing of materials, analysis of research results, conclusions; Zakharash MP concept and design of research, discussion of results; Kuryk OG - conducting morphological research.

Conflict of interest. There are no potential or obvious conflicts of interest associated with this manuscript at the time of publication.

\section{References}

1. Foxx-Orenstein AE, Umar SB, Crowell MD. Common anorectal disorders. Gastroenterol Hepatol (N Y). 2014 May;10(5):294-301. PMID: 24987313; PMCID: PMC4076876.

2. Bach HH 4th, Wang N, Eberhardt JM. Common anorectal disorders for the intensive care physician. J Intensive Care Med. 2014 NovDec;29(6):334-41. doi: 10.1177/0885066613485347. Epub 2013 Apr 22. PMID: 23753241.

3. Borota AV, Kukhto AP, Baziyan-Kukhto NK, Borota AA. Comparative analysis of surgical treatment of the combined non-tumor anorectal pathology. Neoplasm. 2018;10(1):18-21. Russian. doi: 10.26435/neoplasm.v10i1.242.

4. Wald A, Bharucha AE, Cosman BC, Whitehead WE. ACG clinical guideline: management of benign anorectal disorders. Am J Gastroenterol. 2014 Aug;109(8):1141-57; (Quiz) 1058. doi: 10.1038/ ajg.2014.190. Epub 2014 Jul 15. PMID: 25022811. 


\section{КАінічна хірургія}

5. Andreev AL. Laser hemorroidoplasty (LHP) and mucopexia (RAR) in the treatment of chronic combined hemorrhoids stage 3-4. Coloproctology. 2018; (2S): 9-9. Russian.

6. Gain MY, Shakhrai SV, Gain YM. Hemorrhoidal laser coagulation and mucopexy in the surgery of grade ii and iii chronic hemorrhoids: A randomized trial. Novosti hirurgii. 2015; 23(4):429-35. Russian. doi: 10.18484/2305-0047.2015.4.429.

7. Cherepenin MJu, Gorskij VA, Armashov VP. Results of treatment of hemorrhoids by submucosal w-laser destruction of hemorrhoidal piles. Coloproctology. 2020; 19(2): 104-11. Russian. doi:10.33878/2073-7556-2020-19-2-104-111.

8. De Nardi P, Tamburini AM, Gazzetta PG, Lemma M, Pascariello A, Asteria CR. Hemorrhoid laser procedure for second- and thirddegree hemorrhoids: results from a multicenter prospective study. Tech Coloproctol. 2016 Jul;20(7):455-9. doi: 10.1007/s10151-0161479-6. Epub 2016 May 11. PMID: 27164931.

9. Maloku H, Gashi Z, Lazovic R, Islami H, Juniku-Shkololli A. Laser Hemorrhoidoplasty Procedure vs Open Surgical Hemorrhoidectomy: a Trial Comparing 2 Treatments for Hemorrhoids of Third and Fourth Degree. Acta Inform Med. 2014 Dec;22(6):365-7. doi: 10.5455/aim.2014.22.365-367. Epub 2014 Dec 19. PMID: 25684841; PMCID: PMC4315650.
10. Naderan M, Shoar S, Nazari M, Elsayed A, Mahmoodzadeh H, Khorgami Z. A Randomized Controlled Trial Comparing Laser Intra-Hemorrhoidal Coagulation and Milligan-Morgan Hemorrhoidectomy. J Invest Surg. 2017 Oct;30(5):325-31. doi: 10.1080/08941939.2016.1248304. Epub 2016 Nov 2. PMID: 27806213.

11. Giamundo P, Cecchetti W, Esercizio L, Fantino G, Geraci M, Lombezzi R, et al. Doppler-guided hemorrhoidal laser procedure for the treatment of symptomatic hemorrhoids: experimental background and short-term clinical results of a new mini-invasive treatment. Surg Endosc. 2011 May;25(5):1369-75. doi: 10.1007/s00464010-1370-x. Epub 2010 Oct 26. PMID: 20976499.

Received: 30.12.2020 